\title{
INCIDENCE OF PREDATORS AND ANTHROPOGENIC ACTIVITIES AFFECTING BEEKEEPING IN NIGERIA
}

\author{
Lawal, A.A ${ }^{1 *}$, Mustapha $\mathbf{S}^{2}$ and Oyerinde $\mathbf{A} \cdot \mathbf{A}^{\mathbf{3}}$ \\ ${ }^{* 1,3}$ Department of Crop Protection, Faculty of Agriculture, University of Abuja, Abuja. \\ ${ }^{2}$ Department of Crop Protection, Faculty of Agriculture, University of Ilorin.
}

*Corresponding Author: -

Email ID - princeadebowale639@gmail.com

\begin{abstract}
: -
This study evaluated the incidence of predators and anthropogenic activities affecting beekeeping in Nigeria. Questionnaires were administered in Oyo, Ogun and Osun States in the Forest Vegetation and Kaduna, Niger and Kano States in the Savanah vegetation zones of Nigeria. Data obtained were analyzed with parametric statistical tool of mean. The result showed that the largest populations of beekeepers were BachelorDegree and National Certificate in Education NCE holders (25.0\% each), MSc (8\%), National Diploma ND (8\%) and Postgraduate Diploma PGD (9\%). Assessment of human activities that were harmful to beekeeping identified by respondents in the forest vegetation zones revealed indiscriminate use of pesticide (16.67\%), theft (33.33\%) and herdsmen activity (cattle rearing) (31.82\%) while savannah vegetation zones had the following record, indiscriminate use of pesticide (25.00\%), theft (35.33\%) and herdsmen activity (35.71\%). Avoidance of scattering honeybee (Apis mellifera L.) combs around the apiary was found as the most effective method in preventing spread of insect pests. Other methods include hive sanitation, hive positioning, handpicking of insects, the use of spent engine oil, regular weeding, fencing of apiary and use of bee pen. The hives painted with green coloured paint was reported by respondent to control wasp, spider, termites and lesser wax moth. Beekeepers reported weeding as the most effective method used in controlling predators as it was noted that apiaries regularly weeded controlled the following predators with their respective incidence level: rat (8.33\%), snake (12.50\%), toad (29.7\%), frog $(20.83 \%)$ and ghecko (37.50\%) while the most significant was lizard incidence which was $54.17 \%$. Report from respondents on traditional methods to detect apiary problems categorized into predator and human activities include: decreasing size of colony, majority of bees staying outside the hive, sighting of pests in the apiary and abscondment of bees while human interference was noticed with dead bees found in andoutside the hive, inactive bees, trace of burnt grasses and shrubs in the apiary and felled hives from stands.
\end{abstract}

Keywords: - Apiary, predators, pests

\section{(우 (\$) (1)}




\section{INTRODUCTION}

The honeybees, Apis mellifera L., is an insect of crucial economic, agricultural, and environmental importance. A. mellifera adansonii is about the most common species that has been given due attention in Nigeria probably because of its beneficial attributes as a natural agent of pollination and the most important of all insect pollinators (Akunne, 2015). Apis mellifera produce valuable products including honey without competing with other activities of agriculture and forestry. Moreover, as an insect pollinator responsible for regeneration of flowering plants, vegetables and tree crops through pollination services that play an important role in promoting agriculture and forestry (Nakamura et al., 2009). A wide variety of pests and predators are known to attack adult honeybees, bee brood stages, materials stored in the hive and even the hive structure (Vejsnaes,2010). Some of these organisms may simply use the hive as a place to live or as a shelter for their own nest, but some may cause harm by feeding on honey, pollen, brood remains or beeswax (Barasa, 2005).

Appropriate pest and disease control methods requires proper recognition of the causal organism. Apart from mechanical control methods of dealing with the obvious insect pests, rational means of control could only arise after the cause of the injury has been known (Barasa, 2005).

Research on Honeybee Pests and Practical knowledge on its identification and development of appropriate control measures are highly essential in beekeeping sector. With this understanding, the existing literatures indicated that a number of assessments were conducted in different parts of the country at different beekeeping seasons with the objectives of identifying local honeybee pests along with their distribution ranges and kinds of products they affect accordingly.

Previous findings indicated that more than 15 honeybee pests have been identified and recorded with the products types they are affecting (Desalegn and Yosef, 2005; Desalegn et al., 2006). Ants (different types), wax moths (greater and lesser wax moths), mice, birds (different types), honey badger, wasps, death's head hawks moth, bee lice (Braulacoeca), beetles (different types), lizards, toads/frog, praying mantis, spiders, pseudo scorpion were among the major honeybee pests, anthropogenic activities and predators were reported (Lawal et al., 2020).

Honeybee pests are known to cause losses and to transmit viral pathogens for which therapies remain nonexistent and continue to be challenging to eradicate (Geiger et al., 2010). These disturbing trends have stimulated debates and remedial actions from the public, policy makers and scientists which have resulted in unprecedented focus on pollinator health, especially those of honeybees (Pirk et al., 2015). This has resulted in an upsurge in global honeybee research in a bid to provide both shortand long term solutions that will ensure their survival and continual provision of pollination services (Plettner et al., 2017).

\section{Materials and methods}

Questionnaires were administered in both forest (Oyo, Ogun and Osun states) and savanna (Niger, Kaduna and Kano states) zones of Nigeria. Data for the study were gathered from responses of a total number of 240 respondents, i.e. 40 from each state. The questionnaires were administered to members of the Federation of Beekeepers Association of Nigeria (FEBKAN) in each of the study sites. Responses were obtained from beekeepers and analyzed with the use of descriptive and inferential analytical tools such as percentages and charts

\section{Data Analysis}

The administered questionnaires were analyzed with SPSS version 18. The data were divided into forest and savannah vegetation zones. The analysis includes descriptive statistic and presentation in Bar and pie chart showcasing the pattern of responses. Standard error of mean was used to show the variation and precision of the social economic data. The socioeconomic data was also subjected to Analysis of Variance (ANOVA). Significant means were separated with Duncan Multiple Range Test (DMRT).

\section{Educational Qualification of Beekeepers}

The result showed that $25 \%$ of the respondents were Bachelor degree holders in both forest and savannah vegetation zones, NCE holders constitute $25 \%$ in the forest zone and $8 \%$ in the savannah zone and respondents with primary school leaving certificates has $25 \%$ in the forest zone and $8 \%$ in the savannah zone, the percentage of respondents with no formal education was $25 \%$ in the savannah zone, $8 \%$ of the respondents from both forest and savannah vegetation zones had Master's degree and National Diploma while $17 \%$ of the respondent from the savannah vegetation zone had Senior School Certificate as showed in (Figure 1). 


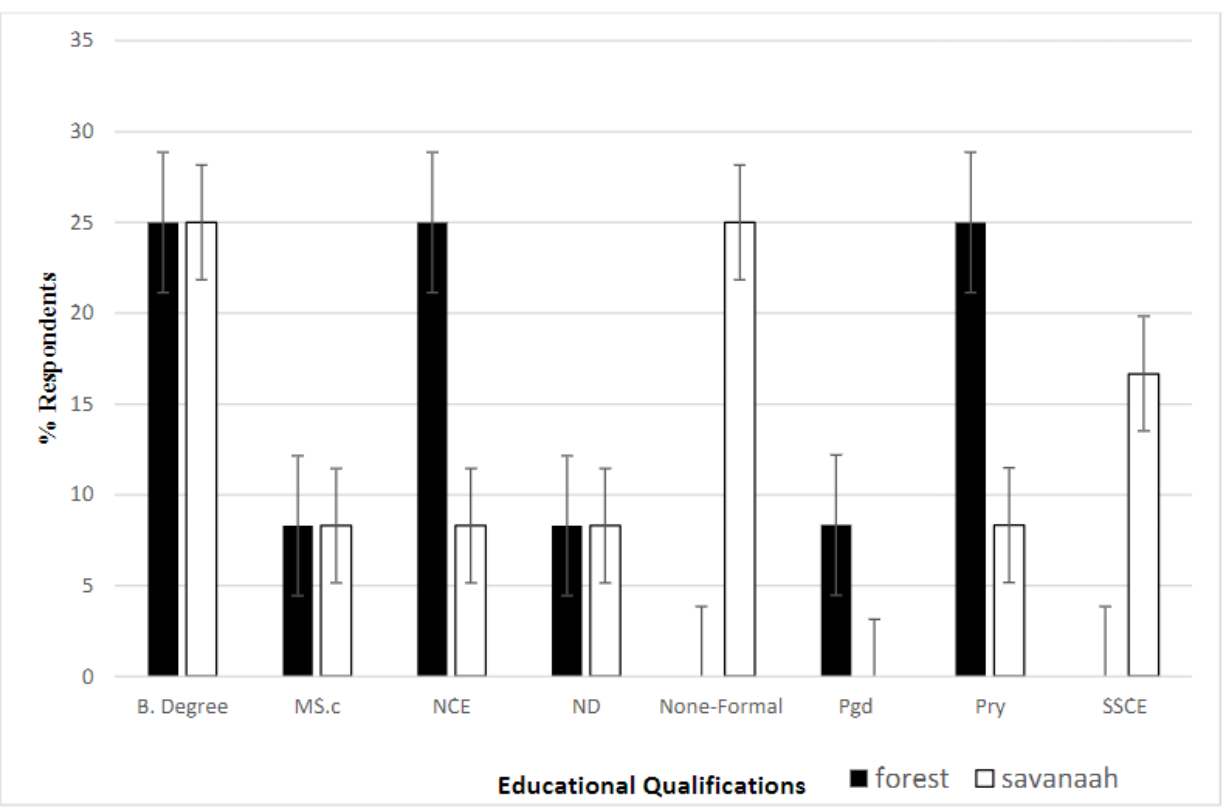

FIGURE 1: Educational qualification of beekeepers

keys: Bachelor's degree (B.degree), Masters of Science (M.Sc.), Nigeria college of education (NCE), National diploma (ND), Postgraduate diploma (pgd), Primary school leaving certificate, secondary school certificate (SSCE)

\section{Anthropogenic Activities Affecting Beekeeping in Nigeria}

Based on the results of this study, one of the major menaces that has effect on beekeeping is the anthropogenic activities which includes: bush burning, theft, herdsmen clash with beekeepers which usually lead to vandalization of bee hives and other apiary inputs, bee poisoning due to agro-chemicals.

Incidence of Anthropogenic Activities Affecting Beekeeping in Forest Vegetation Zones The respondents from the forest vegetation zones rated bush burning having the mean value of $31.82 \%$, indiscriminate use of pesticide $16.67 \%$, theft $33.33 \%$ and cattle rearing $31.82 \%$. The detailed result was shown in Table 1.

Table 1: Incidence of Human Activities Affecting Beekeeping in Forest Vegetation Zones of Nigeria

\begin{tabular}{lllll}
\hline State & Bush burning $\%$ & Pesticide use $\%$ & Theft $\%$ & Cattle rearing $\%$ \\
\hline Ogun & 36.36 & 16.67 & 33.33 & 36.36 \\
Osun & 27.27 & 16.67 & 33.33 & 27.27 \\
Oyo & 36.36 & 66.67 & 33.33 & 36.36 \\
Mean & 31.82 & 16.67 & 33.33 & 31.82 \\
\pm SEM & 3.03 & 16.67 & 0.00 & 3.03 \\
\hline
\end{tabular}

Incidence of Anthropogenic Activities Affecting Beekeeping in Savannah Vegetation Zones

The respondents from the savannah vegetation zones rated bush burning having the mean value of $33.33 \%$, indiscriminate use of pesticide $25.00 \%$, theft $35.33 \%$ and cattle rearing $35.71 \%$. The detailed result was shown in Table 2.

Table 2: Incidence of Human Activities Affecting Beekeeping in Savannah Vegetation Zones

\begin{tabular}{lllll}
\hline State & Bush burning $\%$ & Pesticide use $\%$ & Theft $\%$ & Cattle rearing \% \\
\hline Kano & 33.33 & 0.00 & 30.00 & 28.57 \\
Kaduna & 33.33 & 50.00 & 40.00 & 42.86 \\
Niger & 33.33 & 50.00 & 30.00 & 28.57 \\
Mean & 33.33 & 25.00 & 35.00 & 35.71 \\
\pm SEM & 0.00 & 16.67 & 3.33 & 4.76 \\
\hline
\end{tabular}

Effectiveness of Weeding in the Control of Predators

Another traditional method used by beekeepers for predators' control was weeding so as to make the apiary free of bushes which was documented and categorized according to whether the beekeepers considered them to be either effective or non-effective (Figure 4.7). Weeding was reported to be most effective in the control of rat $8.33 \%$, snake $12.50 \%$ while the most significant was lizard incidence which was $54.17 \%$. 


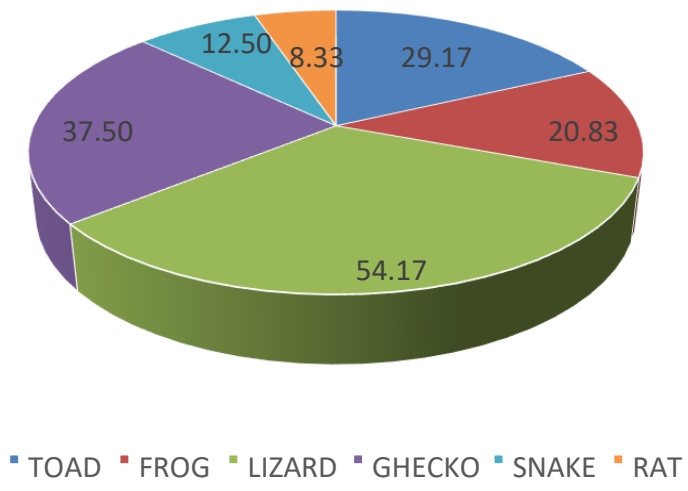

FIGURE 2: Efficacy of Weeding in the Control of Predators in Beekeeping

Incidence of Predators Affecting Honeybees in the Forest vegetation Zones

The beekeepers categorized the prevalence of honeybee predators according to how they perceived these predators to be most common (Figure 4.8). Lizard appeared to have the incidence 35\%, other predators includes toad, gecko and rat having the following percentages $25 \%, 30 \%$ and $10 \%$ respectively.

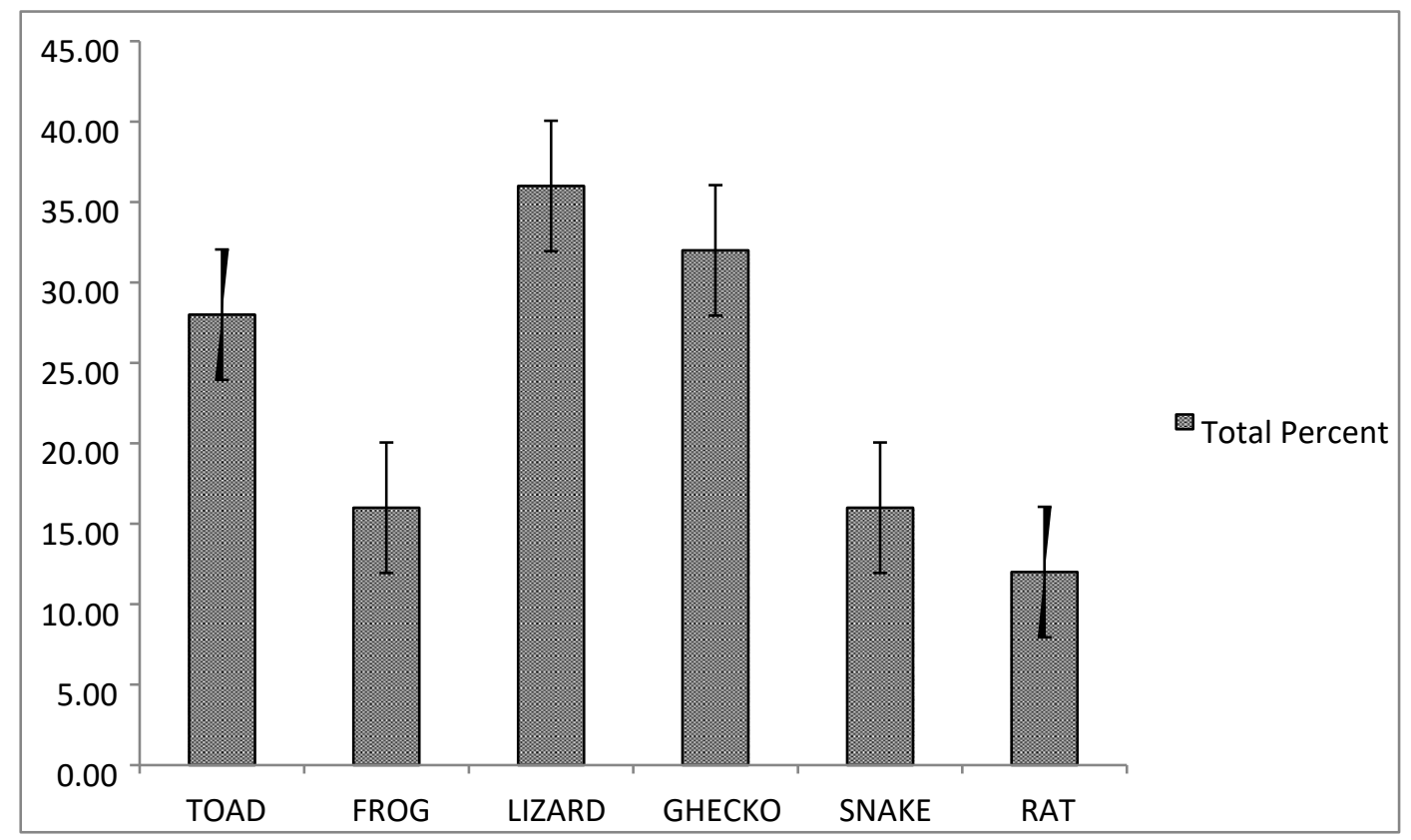

FIGURE 3: Incidence of Predators Affecting Honeybees in the Forest vegetation Zones

Lizard appeared to have the incidence $45 \%$, other predators include toad, gecko, frog and rat having the following percentages $18 \%, 24 \%, 8 \%$ and $5 \%$ respectively. 


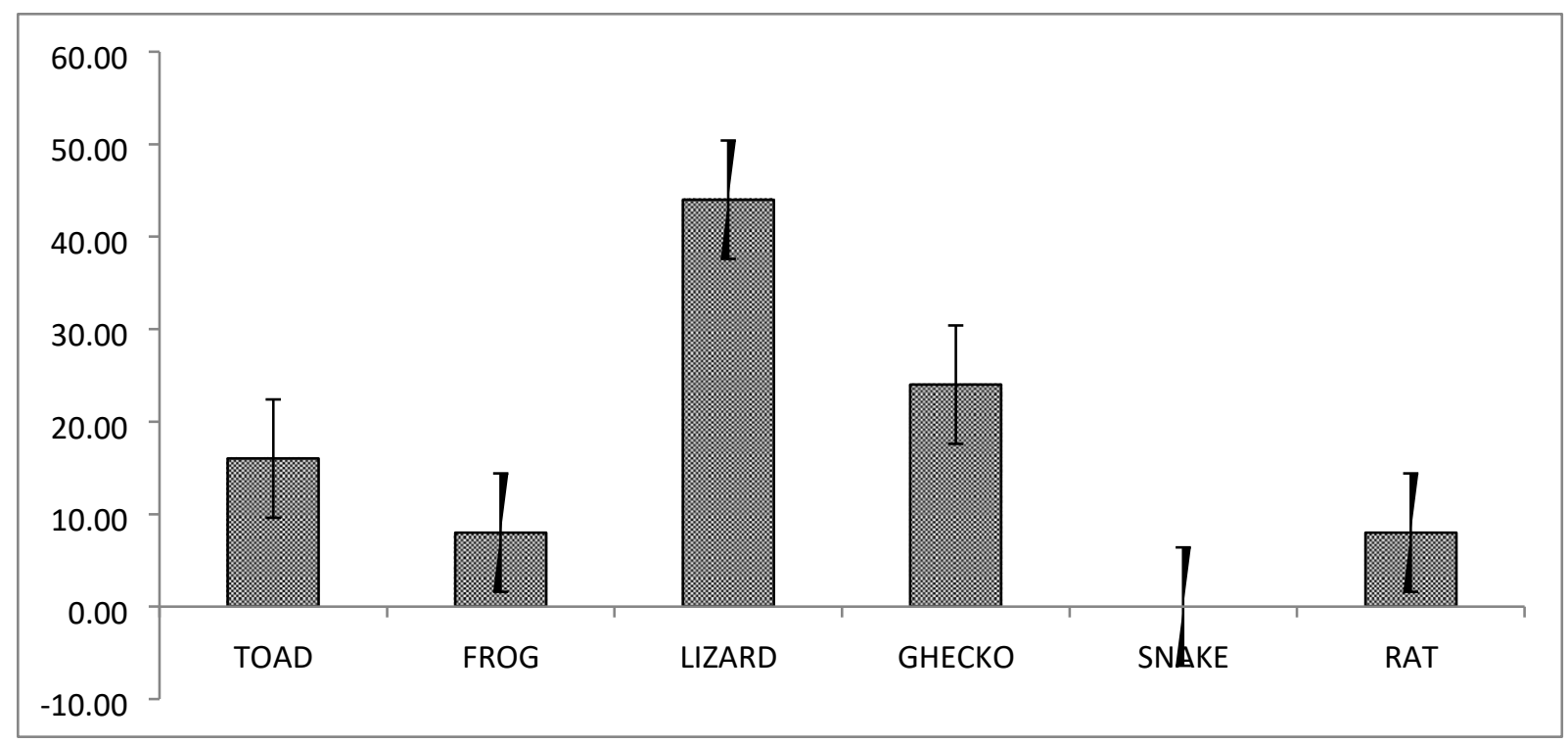

FIGURE 4: Prevalence of Predators Affecting Honeybees in the Savannah vegetation Zones

\section{Traditional Method of Diagnosing Problems in Apiary}

Traditional methods used by beekeepers to diagnose honeybee pests and human activities causing problem to beekeeping were documented, symptoms that beekeepers use to diagnose presence of pests include: Majority of bees staying outside the hives, decreasing size of bee colony, sighting of pest in the apiary, Unusual absconding of bees, Unstable flight of bees, Presence of pest inside the hive when inspected, Empty hives left with combs during harvesting, unusual hooming in the Apiary and decreasing size of bee colony while human activities causing problems to beekeeping are detected as reported by respondents to be dead bees found in and outside the hive, Inactive bees found in and outside the hives, trace of burnt grasses, shrubs in the apiary, felled hives from stands, observed physically damaged hives and strange stinging of people even far away from the location of beehives/Apiary.

\section{Conclusion}

This study established that beekeeping in Nigeria was significantly affected by predators which are toad, frog, lizard, snake, gecko, rat and human activities which includes bush burning, pesticide use, theft and cattle rearing.

\section{References}

[1].Akunne, C.E. (2015) The Rudiments of Beekeeping. Divine Press and Publishers, Awka, Nigeria, pp. 52.

[2].Barassa, P. (2005) Assessment of farmers' awareness and perceptions on local control methods of pests and diseases in Agro-forestry system of Budongo sub-county, Masindi district, Uganda Journal of Agricultural science pp 520-529.

[3].Desalegn, B. (2006). Occurrence of small hive beetle (Aethinatumida Murray; Coleoptera: Nitidulidae) in honeybee (A.mellifera L.) in Ethiopia. Ethiopian veterinary journal 2006, 10(2): 101-110. Addis Ababa, Ethiopia.

[4].Desalegn, B. and Yosef, K. (2005). Survey of Honeybee pests and pathogens in Addis Ababa Region. $5^{\text {th }}$ Proceedings of Annual Conference of Ethiopian Beekeeping Association. Addis Ababa, Ethiopia.

[5].Geiger F, Bengtsson J., Berendse, F., Weisser, WW., Emmerson, M., Morales, MB., Ceryngier, P., Liira, J., Tscharntke, T., Winqvist, C., Eggers, S., Bommarco, R., Pärt, T., Bretagnolle, V., Plantegenest, M., Clement, LW., Dennis, C., Palmer, C., Oñate, J.J., Guerrero, I., Hawro, V., Aavik, T., Thies, C., Flohre, A., Hänke, S., Fischer, C., Goedhart, P.W. AndInchausti, P. (2010). Persistent negative effects of pesticides on biodiversity and biological control potential on European farmland. Basic Appl. Ecol 11:97-105.

[6].Lawal A. A., Oyerinde A. A., Asala S. W. and Anjorin T. S. (2020). The incidence and management of pest affecting honeybees in Nigeria. Global journal of Bio-science and biotechnology pp 40-44.

[7].Nakamura, J., Gikungu, M. W., Kano, Y., Hanzawa, K., Gichora, M., Morimoto, Y., Ogawa, H., Fujiyosi, H. and Udagawa, R, (2009). Development of Beekeeping in Developing Countries and Practical Procedures, Case Study in Africa .JAICAF, Japan. www.jaicaf.or.jp/English/bee_en.pdf18(12)

[8].Pirk C.W., Strauss U., Yusuf A.A., Démares F. and Human H. (2015). Honeybee health in Africa A review. Apidologie. ;47:276-300. doi: 10.1007/s13592-015-0406-6.

[9].Plettner, E., Eliash, N., Singh, N.K., Pinnelli, G.R. andSoroker, V. (2017). The chemical ecology of host-parasite interaction as a target of Varroa destructor control agents. Apidologie. ;48:78-92. doi:10.1007/s13592-016-0452-8. 